\title{
Soil Temperature Patterns During the First Sugarcane Growth Stages Under a Different Crop Management in the Cauca River Valley, Colombia
}

\author{
Andrés Javier Peña Quiñones ${ }^{1}$ \& Christian José Mendoza Castiblanco ${ }^{2}$ \\ ${ }^{1}$ Agrometeorology Service, Centro de Investigación de la Caña de Azúcar de Colombia, Cenicaña, Colombia \\ ${ }^{2}$ Agronomy Program, Centro de Investigación de la Caña de Azúcar de Colombia, Cenicaña, Colombia \\ Correspondence: Andrés Javier Peña Quiñones, Cenicaña, Km 26 vía Cali-Florida, Florida, Valle del Cauca, \\ Colombia. Tel: 57-2-524-6611. E-mail: ajpena@cenicana.org
}

$\begin{array}{lr}\text { Received: July 21, } 2020 & \text { Accepted: August 23, 2020 Online Published: September } 15,2020 \\ \text { doi:10.5539/jas.v12n10p225 } & \text { URL: https://doi.org/10.5539/jas.v12n10p225 }\end{array}$

\begin{abstract}
For several years, the Colombian sugarcane industry had sugar and ethanol as its primary products. However, during the last years, sugar mills opened a new market based on products before considered waste. This new market offers a new possibility for harvest-waste utilization. However, if the waste becomes an income source, crop management will change. Collecting sugarcane waste for its utilization in making some other products, would mean a new crop management scenario left the soil bare soil during the first stages of planting and ratoon canes. We simulated a bare soil condition using mesocosms, for the three most representative soil textures of the Cauca river valley, and we measured soil temperature at different depths during the most convenient planting season (March-April). Results demonstrated differences in soil temperature patterns, especially in sandy soils, which tend to have higher thermal amplitudes in all layers. The parameters of linear regressions that relate temperature of layers, including air temperature, give information related to the thermal properties of soils, and therefore, it is possible, under Cauca Valley conditions, in the future to infer soil temperature from air temperature.
\end{abstract}

Keywords: thermal properties, thermal amplitude, ambient temperature, root zone temperature

\section{Introduction}

In the Cauca River Valley, a Colombian region with lands belonging to five departments, Cauca, Valle del Cauca, Quindío, Risaralda, and Caldas, there are around 250,000 ha of sugarcane. In this region, 13 sugar mills crush about 24 million tons of sugarcane sticks per year (Asocaña, 2020). Even though the sugar mills' original objective, 50 to 120 years ago, was to produce raw and white sugar, today, they also produce ethanol, electric energy, paper, and biofertilizers (Asocaña, 2020). Despite the diversification, the excess of biomass - specifically, straw-left in the field after harvesting has attracted the attention of sugar mill managers. In Brazil, straw could represent up to twenty tons of dry mass per hectare (Tenelli et al., 2019), and in Colombia, this value could be even higher. Straw, which became a problem after no-burn sugarcane management became prevalent (e.g., Preciado et al., 2020), was initially used as a source of organic matter for soils. Nowadays, harvest residues are projected to be used as a raw material for producing ethanol, bricks, and briquettes (Tenelli et al., 2019; Santos et al., 2012; Tumuluru et al., 2014).

The export of all straw from the field to the factories do alter more than yields (e.g., Tenelli et al., 2019). A bare-soil after harvest will assume an energy balance alteration in comparison to having a mulch after harvest (Davin et al., 2014). Crop residue mulches have higher albedo values than bare soils (White, 2015; Davin et al., 2014), which reduces the available energy for heating the soil. The average difference between bare-surfaces albedo and mulch-surfaces albedo fluctuates around ten percentage points (Davin et al., 2014). In the Cauca valley conditions (Peña et al., 2020), that difference in albedo values would mean around $2 \mathrm{MJ} / \mathrm{m}^{2} / \mathrm{day} \mathrm{more}$ of net radiation in bare-soil surfaces. The excess net radiation in bare soils implies more energy available for soil heating (White, 2015), and therefore, these soils have higher temperatures than mulched surfaces (Bragagnolo \& Mielniczuk, 1990). 
This study's goal was to determine the consequences of a new sugarcane management scenario on soil temperature patterns. Although the measurements of soil temperature in Colombia are scarce, this value is valuable for agriculture (Oliveira et al., 2001). Soil environment actively contributes to plant growth and development, affecting nutrient and water uptake (Valverdi, 2019). According to Marin (2008), soil temperatures between 32 and $38^{\circ} \mathrm{C}$ are ideal for the germination of buds in sugarcane stalks. Hunsigi (1993) reported that dry matter and stalk elongation increased with an increase in air temperature from 17.2 to $22.2{ }^{\circ} \mathrm{C}$ and with an increase in soil temperature from 12.8 to $21.1{ }^{\circ} \mathrm{C}$. Specifically, James (2004) defined $35{ }^{\circ} \mathrm{C}$ like the optimal temperature for root growth; but, Whiteman (1963) considered that the optimum temperature is variety specific. On the other hand, soil temperature alters organic matter decomposition rate and mineralization (Onwuka and Brown, 2018). According to these authors, most soil microorganisms require temperatures between $10{ }^{\circ} \mathrm{C}$ and $35^{\circ} \mathrm{C}$ for their activities, while soil macroorganisms increase their metabolic rate between $10{ }^{\circ} \mathrm{C}$ and $24{ }^{\circ} \mathrm{C}$.

Considering that soil temperature is a not a continuously measured variable, to know that specific information without on-site sensors is a challenge. Obtaining soil temperature data with no direct measurements has been an essential topic for agricultural researchers. By solving, simultaneously, Fourier's law and the continuity equation, several authors (e.g., Campbell \& Norman, 1998, Moene \& van Dam, 2014) obtained a term that is useful in simulating the soil temperature patterns in space and time. Campbell and Norman (1998) offered a simple solution to that term. The basis of the solution is the knowledge of average soil surface temperature and damping depth.

Damping depth, a soil parameter that describes how much the thermal amplitude in the soil is attenuated by depth, becomes a parameter for replacing thermal diffusivity and volumetric heat capacity. With that in mind, what we wanted with this experiment was to define the soil temperature pattern, in a recommended sowing season, at four depths, in three typical soils of the Cauca River Valley. In 2020, the recommended sowing season runs from March to April. The second objective was to determine the relationship between air temperature and soil temperature. Both objectives are the first steps for obtaining an empirical model for inferring soil temperature based on air temperature. This is the reason why we decided to relate air and soil temperature. Contrary to soil surface temperature, which is the variable used by Campbell and Norman (1998) for obtaining internal soil temperature, air temperature is widely measured in the region. It is important to mention that this work was not designed for finding differences between mulch and bare soil scenarios or to define differences between current and future climate change scenarios.

\section{Methodology}

\subsection{Location}

The Cauca River valley is in the equatorial region located between $3^{\circ} \mathrm{N}$ and $5^{\circ} \mathrm{N}$ (Appendix A). Therefore, daily values of daylight, air temperature, and global solar radiation have low variation (Figure 1). Because of this condition, sugarcane growers can sow and harvest throughout the year. However, considering there are two rainy seasons and two dry seasons (Figure 1) and bearing in mind that sugarcane production is mechanized, growers prefer dry seasons for sowing and harvesting (ratooning). The transitional periods between dry and rainy seasons (March-April, September-October) are preferred for harvesting, planting, and ratooning. Collecting canes toward the end of the dry season, prior to the rainy season, allows growers conduct agricultural activities with a low impact on the soil and take advantage of the rainy season for the first crop stages. In 2020, the first dry season of the year was longer than usual, lasting until the end of April (Figure 2). 


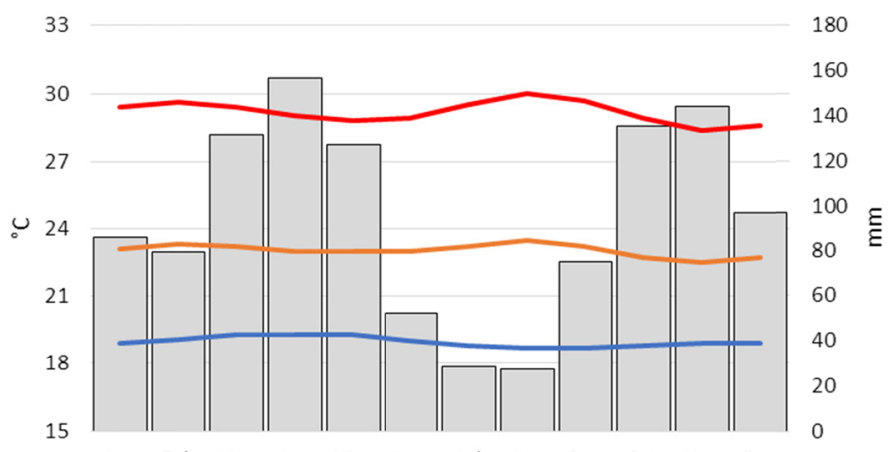

Jan Feb Mar Apr May Jun Jul Aug Sep Oct Nov Dec

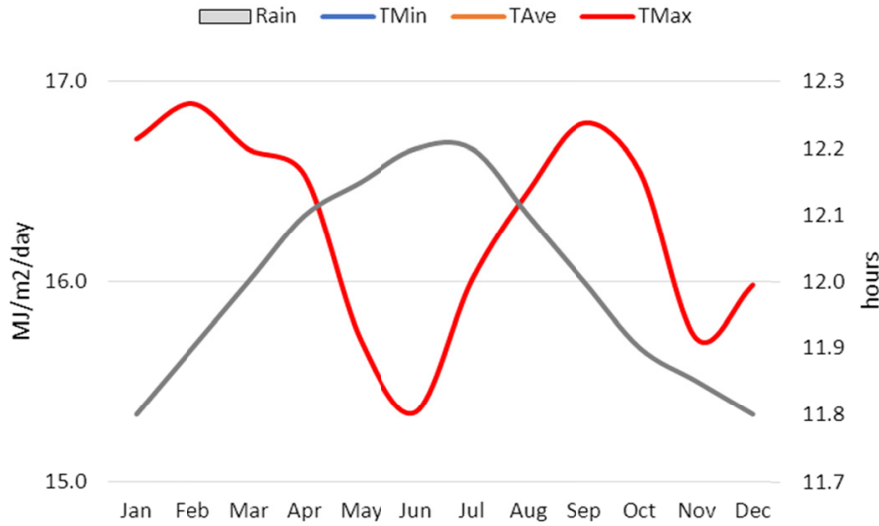

Global Rad _Daylight

Figure 1. Monthly weather patterns at Cenicaña, based on daily data measured at a standard automatized weather station between 1993 and 2019

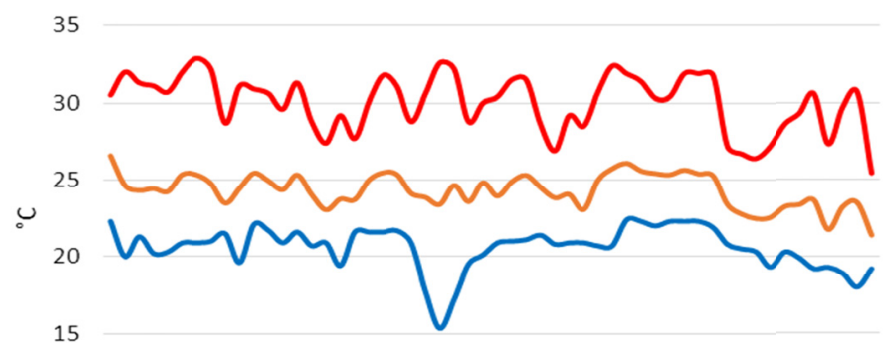

10

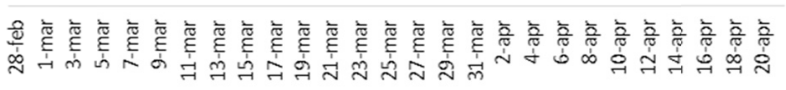

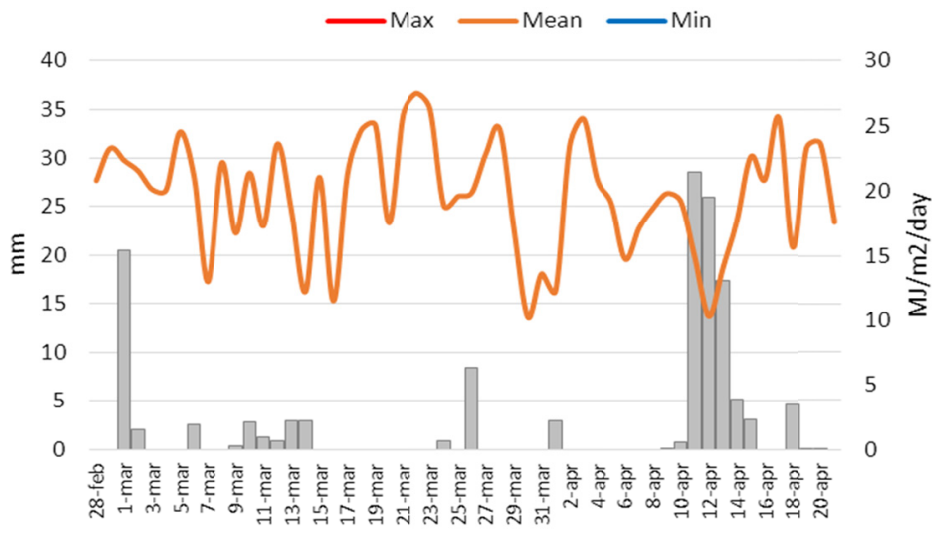

$\square$ Rain Global Rad

Figure 2. Actual weather of the period of the experiment. Data measured at an automatized weather station 


\subsection{Installation}

The experiment was carried out in mesocosms. Mesocosms allowed us to have the representative soils in a same place under the same weather conditions. In this case, three buried pots in the field allowed to control the soil texture and depth of the soil profile in order to compare three different soils with the advantage of doing that in a real field environment. Three pots with a capacity of $0.51 \mathrm{~m}^{3}$, filled with soils of different texture, loam, sand, and sandy clay loam (Table 1), were buried $300 \mathrm{~m}$ from the Cenicaña weather station (Figure 3). This distance means the experimental site is within the radius of influence of air temperature data measured at the weather station (Peña et al., 2019). The pots were buried in a clay soil two months before to start the experiment. Soil within mesocosms was weekly irrigated during the first three weeks with 161 of water per pot $(25 \mathrm{~mm})$, simulating the real management conditions. We installed four type T Omega thermocouples (Norwalk, CT, USA) within each pot, at depths of $0.05 \mathrm{~m}\left(\mathrm{~T}_{5 \mathrm{~cm}}\right), 0.15 \mathrm{~m}\left(\mathrm{~T}_{15 \mathrm{~cm}}\right), 0.25 \mathrm{~m}\left(\mathrm{~T}_{25 \mathrm{~cm}}\right)$, and $0.35 \mathrm{~m}\left(\mathrm{~T}_{35 \mathrm{~cm}}\right)$ under the surface (Figure 3). Precision thermocouples used in this experiment had a diameter of $0.127 \mathrm{~mm}$ (gauge number 36 ). The average air temperature during the experiment, based on hourly data measured at the weather station, was $24.3{ }^{\circ} \mathrm{C}$ with a standard deviation of $3.4^{\circ} \mathrm{C}$. The maximum air temperature reached during this time was $32.9^{\circ} \mathrm{C}$ (March 5), and the daily maximum average air temperature was $30.0^{\circ} \mathrm{C}$. The minimum air temperature reached on those days was $15.4{ }^{\circ} \mathrm{C}$ (March 22), while the minimum average air temperature was $20.6{ }^{\circ} \mathrm{C}$ (Figure 2).

Table 1. Texture characteristics of soils submitted to evaluation in the mesocosms

\begin{tabular}{llllll}
\hline Soil & Depth & Sand & Clay & Silt & Bulk density \\
\hline & & $-1.0-0$ & -1.4 & 1.27 \\
Loam & $0.0-0.2 \mathrm{~m}$ & 44.0 & 24.5 & 31.4 \\
Loam & $0.2-0.4 \mathrm{~m}$ & 42.6 & 24.7 & 32.7 & 1.15 \\
\hline Sand & $0.0-0.2 \mathrm{~m}$ & 96.4 & 2.7 & 0.9 & 1.48 \\
Sand & $0.2-0.4 \mathrm{~m}$ & 97.8 & 1.3 & 0.9 & 1.51 \\
\hline SCL $^{*}$ & $0.0-0.2 \mathrm{~m}$ & 53.9 & 24.9 & 21.1 & 1.26 \\
SCL $^{*}$ & $0.2-0.4 \mathrm{~m}$ & 54.3 & 25.6 & 20.1 & 1.31 \\
\hline
\end{tabular}

Note. * Sandy Clay Loam.

\subsection{Data}

The thermocouples installed within the soil were connected to three CR10X Campbell Sci dataloggers (Logan, UT, USA). Four thermocouples and a Campbell Sci CR10TCR device (Logan, UT, USA) were installed on each datalogger. CR10TCR was used as a junction reference for the thermocouples. Dataloggers were programmed to take measurements every 10 seconds and record the average value over one-hour period. Soil temperature was registered for 53 days, from February 28 to April 21, corresponding to 1,299 hourly temperature registers for each depth and mesocosm (Appendix B).

\subsection{Analysis}

We used descriptive statistics to define common soil temperature patterns (time and space). To describe the central tendency, we used the mean and the standard deviation for describing the variability. We applied this analysis at spatial (depth) and temporal levels for the three soil types. In this way, we obtained the mean and standard deviation values for every 24 hours and the four depths. Standard deviation and mean value were used to describe the average hourly air temperature between February 28 and April 21. Finally, we used the same type of analysis to identify the mean difference between day and night at different depths and soils.

We used a correlogram to determine the relationship between the hourly air temperature and the soil temperature time series at different depths. We also generated correlograms to identify the relationship between the soil temperature time series at different depths. In the last case, we related the data from each layer to the immediate above layer, e.g., $\mathrm{T}_{5 \mathrm{~cm}}-$ air temperature, $\mathrm{T}_{15 \mathrm{~cm}}-\mathrm{T}_{5 \mathrm{~cm}}, \mathrm{~T}_{25 \mathrm{~cm}}-\mathrm{T}_{15 \mathrm{~cm}}$, and $\mathrm{T}_{35 \mathrm{~cm}}-\mathrm{T}_{25 \mathrm{~cm}}$. The correlograms, based on the cross-correlation between temperature series, provide information about the time between the peak values in two datasets (Derrick and Thomas, 2004). For instance, results based on this analysis would show the time delay between the maximum air temperature and the maximum soil temperature at different depths. 
a
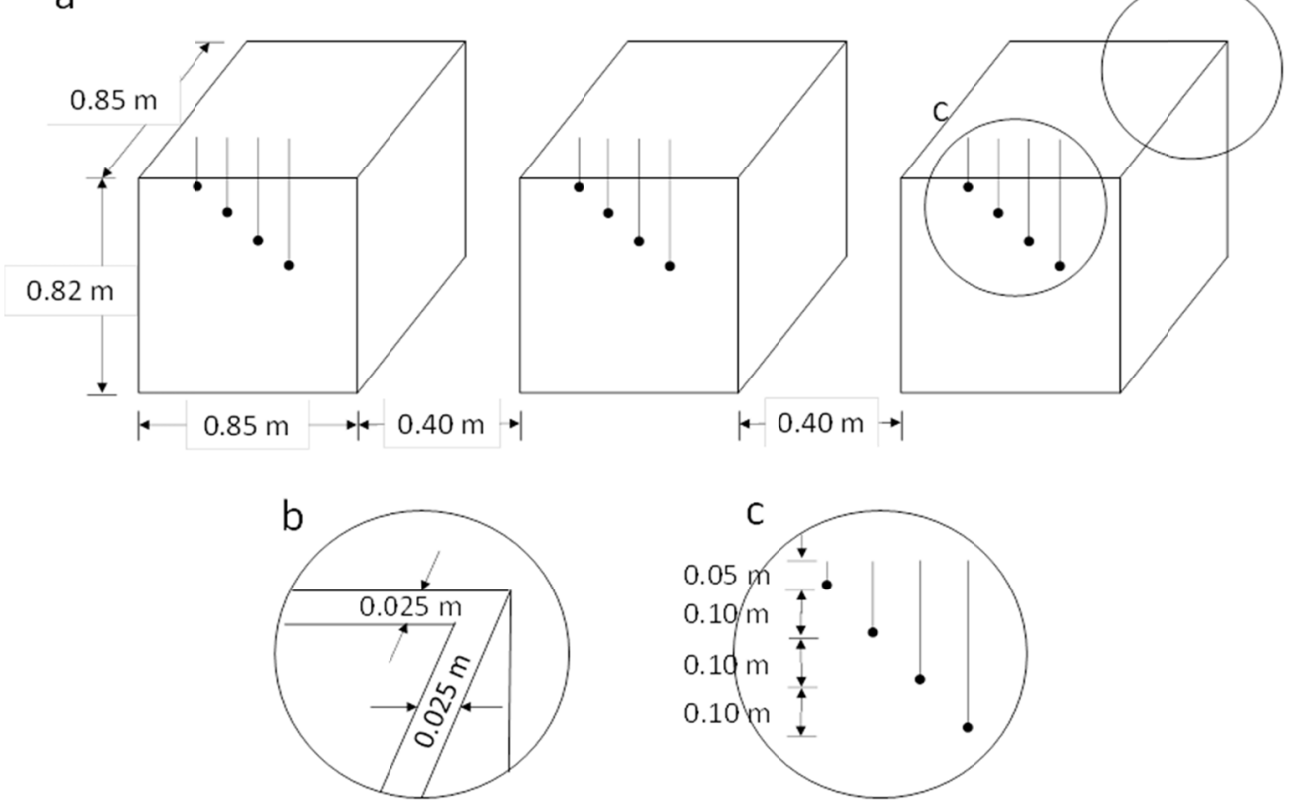

(a)

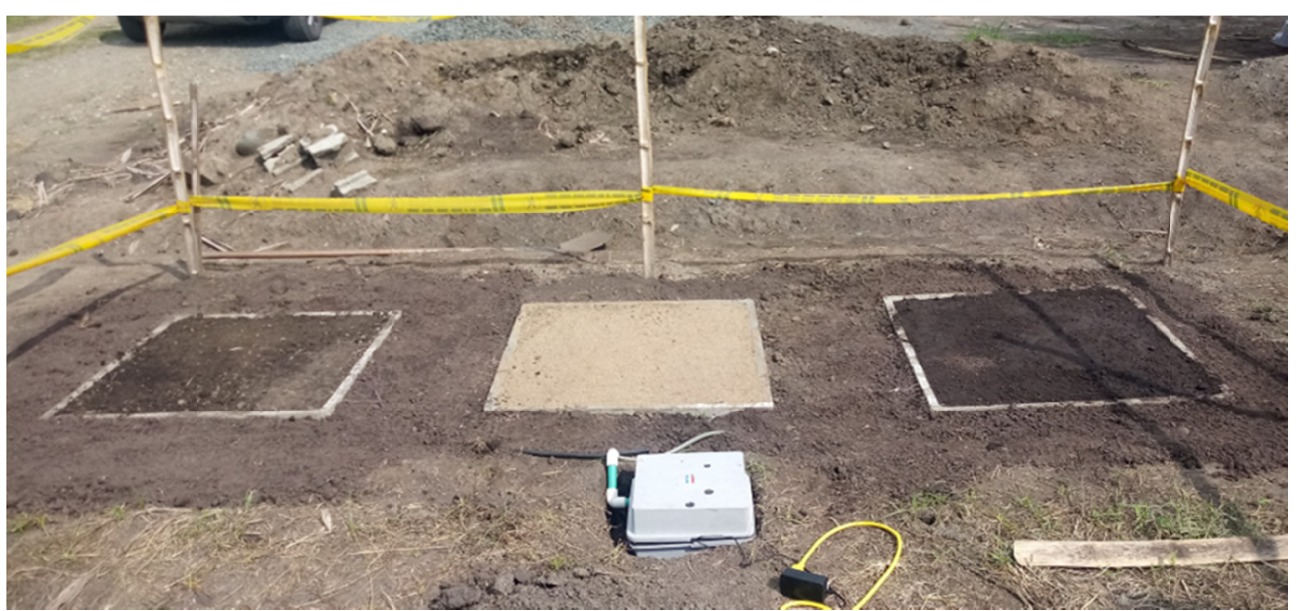

(b)

Figure 3. Mesocosms installation details (a), description of the pots used for the experiment (b) and thermocouples location. Placement details, showing three soil types used: loam (left), sand (middle) and sandy clay loam (right)

\section{Results}

\subsection{Descriptive Analysis}

On a daily basis, the average temperature of the top layer $\left(\mathrm{T}_{5 \mathrm{~cm}}\right)$ did not rendered significant differences among the soil types: $31.9^{\circ} \mathrm{C}$ (loam), $31.6^{\circ} \mathrm{C}$ (sand), and $31.5^{\circ} \mathrm{C}$ (sandy clay loam). In this same layer, the minimum variation of temperature was reached in the loam soil, with a standard deviation value of $4.6^{\circ} \mathrm{C}$ compared to $5.1{ }^{\circ} \mathrm{C}$ and $5.6^{\circ} \mathrm{C}$ for the sand and sandy clay loam soils, respectively (Figure 4). The average temperature of the second layer $\left(\mathrm{T}_{15 \mathrm{~cm}}\right)$ is similar among the soils; however, it is higher in the loam soil $\left(31.3^{\circ} \mathrm{C}\right)$ and lower in the sandy clay loam soil $\left(30.4{ }^{\circ} \mathrm{C}\right)$ and in the sand soil it is $30.9^{\circ} \mathrm{C}$. The previous result also means that the highest rate of decrease of temperature between the first and second layer was reached in the sandy clay loam soil. The second layer did not exhibit significant differences in standard deviation values among soil types: $3.2{ }^{\circ} \mathrm{C}$ (loam and sand) and $3.1{ }^{\circ} \mathrm{C}$ (sandy clay loam) (Figure 4). As occurred in the first layer, there are no differences in the average values of temperature of the third layer $\left(\mathrm{T}_{25 \mathrm{~cm}}\right): 30.7{ }^{\circ} \mathrm{C}$ (loam and sand) and $30.5{ }^{\circ} \mathrm{C}$ (sandy clay loam). The pattern of reduction of variability of soil temperature values with depth continues. Nevertheless, as 
described for the first layer, in this layer, in the sandy clay loam soil, the standard deviation value was lower $\left(2.1^{\circ} \mathrm{C}\right)$ than in the other two soils $\left(2.7^{\circ} \mathrm{C}\right)$. It is essential to point out that there were no differences in the average temperature values of layers two and three in the sand and sandy clay loam soils $\left(0.1{ }^{\circ} \mathrm{C}\right)$, while this difference was $0.6^{\circ} \mathrm{C}$ in the loam soil (Figure 4). In the third layer, there were essential differences in average daily temperature among soil types; $30.8{ }^{\circ} \mathrm{C}$ (loam), $30.1{ }^{\circ} \mathrm{C}$ (sand), and $28.7{ }^{\circ} \mathrm{C}$ (sandy clay loam). The difference between average daily temperature measured in the third and fourth layer $\left(\mathrm{T}_{35 \mathrm{~cm}}\right)$ was almost null in the loam soil $\left(0.1^{\circ} \mathrm{C}\right)$, but different for the other two soils; $0.6^{\circ} \mathrm{C}$ in the sand soil, and $1.7^{\circ} \mathrm{C}$ in the sandy clay loam soil (Figure 4).

Patterns describing the relationship between soil temperature and depth during day and night depends on the type of soil (Figure 5). In the loam soil, the temperature is always higher at night in the three deepest layers $\left(\mathrm{T}_{15 \mathrm{~cm}}\right.$, $\mathrm{T}_{25 \mathrm{~cm}}$, and $\mathrm{T}_{35 \mathrm{~cm}}$ ); meanwhile, in the sand and sandy clay loam soils, the temperature is also higher at night, but only in the two deepest layers (Figure 5). Between $0.1 \mathrm{~m}$ and $0.2 \mathrm{~m}$ of depth $\left(\mathrm{T}_{15 \mathrm{~cm}}\right)$, soil temperature exhibits low variation between day and night. The temperature value reached in this layer was different for the tested soils: $31.4{ }^{\circ} \mathrm{C}$ for the loam soil $(0.12 \mathrm{~m}), 30.7{ }^{\circ} \mathrm{C}$ for the sand soil $(0.16 \mathrm{~m})$, and $30.2{ }^{\circ} \mathrm{C}$ for the sandy clay loam soil $(0.16 \mathrm{~m})$. At night, in loam soils, the average temperature is about $32{ }^{\circ} \mathrm{C}$ in the three deepest layers, and during the day, it is about $30^{\circ} \mathrm{C}$; an inverse pattern was observed in the first layer $\left(\mathrm{T}_{5 \mathrm{~cm}}\right)$, where the average temperature values during the day and night were about $32{ }^{\circ} \mathrm{C}$ and $30^{\circ} \mathrm{C}$, respectively. The sand soil was the one with the highest temperature amplitude in the first $\left(5.5^{\circ} \mathrm{C}\right)$ and the two deepest layers $\left(3.0\right.$ and $2.3{ }^{\circ} \mathrm{C}$, respectively). In the sandy clay loam soil, the pattern is a mixture of loam soil and sandy soil. Thus, temperature amplitude is lower than $3{ }^{\circ} \mathrm{C}$ in the first and the lowest layers, while this parameter tends to be lowest in the fourth layer. In this soil, the fourth layer displays the lowest temperature amplitude between day and night.
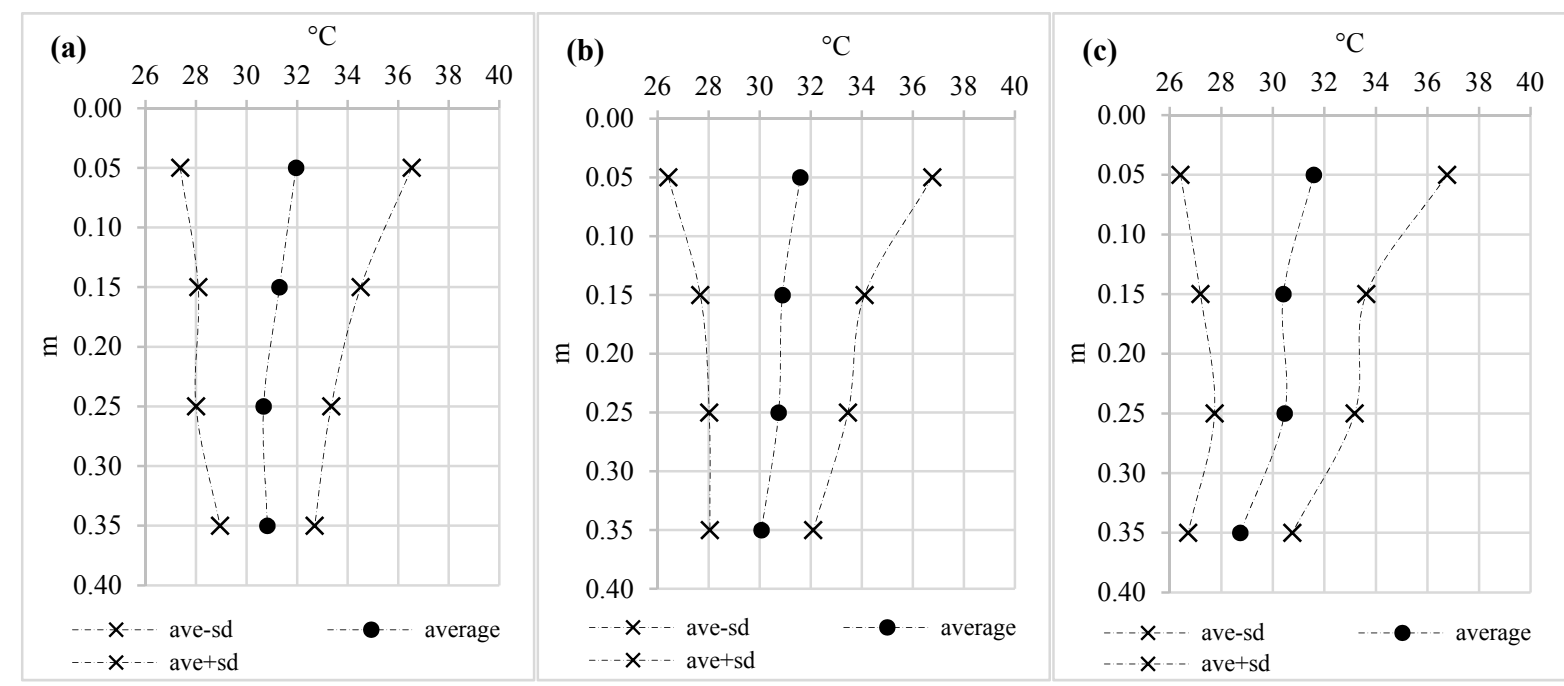

Figure 4. Daily mean and standard deviation of soil temperature values in three soil types: loam (a), sand (b), and sandy clay loam (c) 

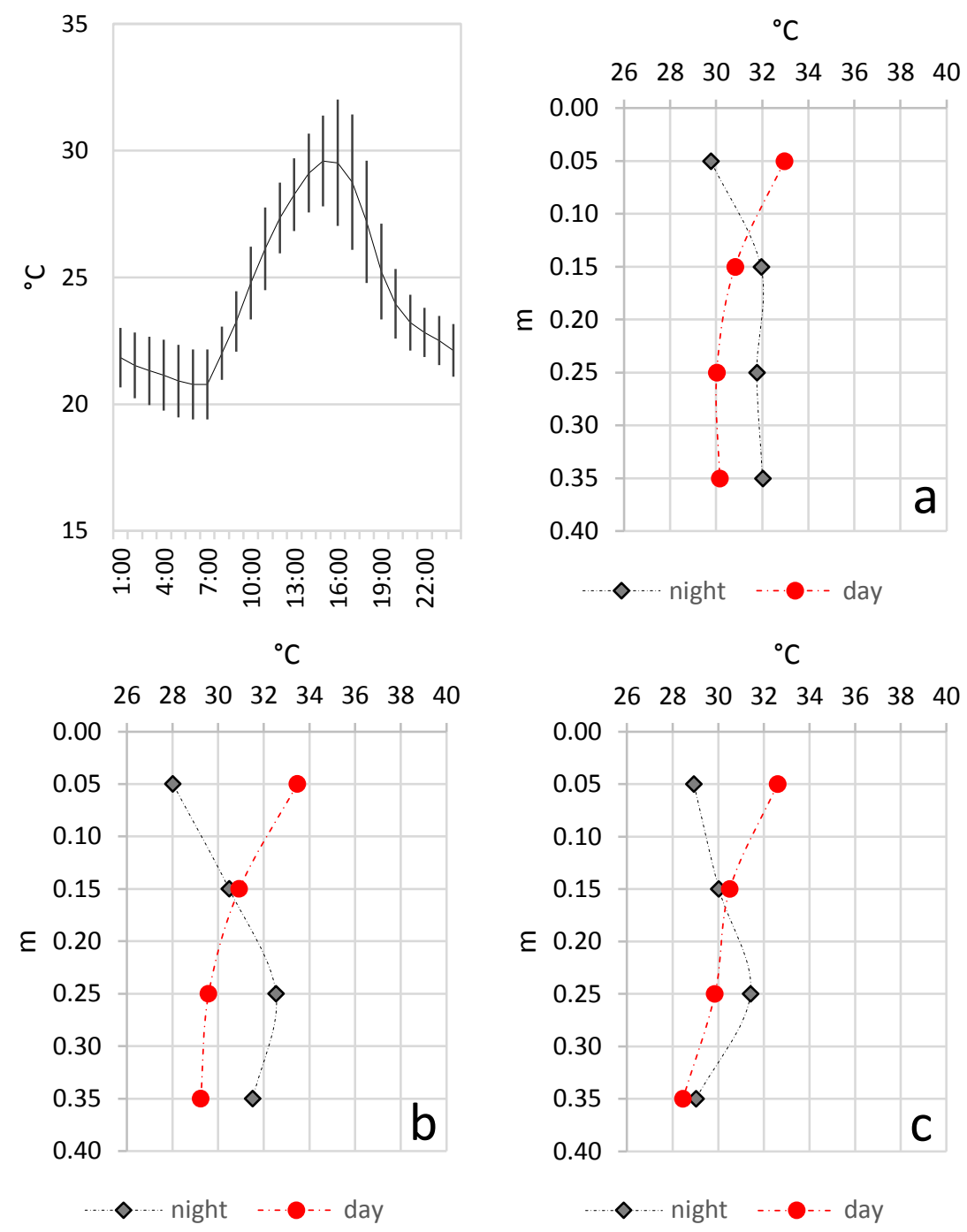

Figure 5. Day (7:00 to 19:00) and night (19:00 to 7:00) temperature mean value in diff erent depths and soils: loam (a), sand (b), and sandy clay loam (c)

At an hourly scale, the topsoil layer $\left(\mathrm{T}_{5 \mathrm{~cm}}\right)$ reached the maximum mean temperature between 15:00 (sand soil) and 16:00 (loam and sandy clay loam soils). The sandy soil reaches the maximum mean temperature simultaneously with the maximum mean air temperature value (Figure 6). The air reached the minimum mean temperature value between 6:00 and 7:00, almost the same hour when the studied soils reach that value, 6:00 in the sand and sandy clay loam soils, and 7:00 in loam soil. The second layer $\left(\mathrm{T}_{15 \mathrm{~cm}}\right)$ reaches the maximum soil temperature about two (loam and sandy clay loam soils) to three hours (sand soil) after the first layer reaches that temperature. The minimum temperature of this layer is reached three to four hours after the first layer reaches that value (Figure 6). The third layer $\left(\mathrm{T}_{25 \mathrm{~cm}}\right)$ reaches the maximum temperature between one (sandy clay loam soil) and two hours (loamy and sandy soils) after the second layer registers that value. In this layer, the minimum temperature arrives around one hour (loam soil) to two hours (sand and sandy clay loam soils) after this temperature was measured in the second layer (Figure 6). The fourth layer $\left(T_{35 \mathrm{~cm}}\right)$ reaches the maximum temperature four hours after the third layer reaches that value in the loam soil. The minimum temperature in the fourth layer is registered two hours after minimum temperatures appear in the third layer (loamy and sandy soils). However, in the sandy clay loam soil, this value is registered two hours previous to that value is reached in the third layer (Figure 6). Finally, the reduction of thermal amplitude between the first and the fourth layer $(0.30 \mathrm{~m})$ corresponds to $72 \%$ (clayey soil), $70 \%$ (sandy soil), and $71 \%$ (loamy soil) (Figure 6). 

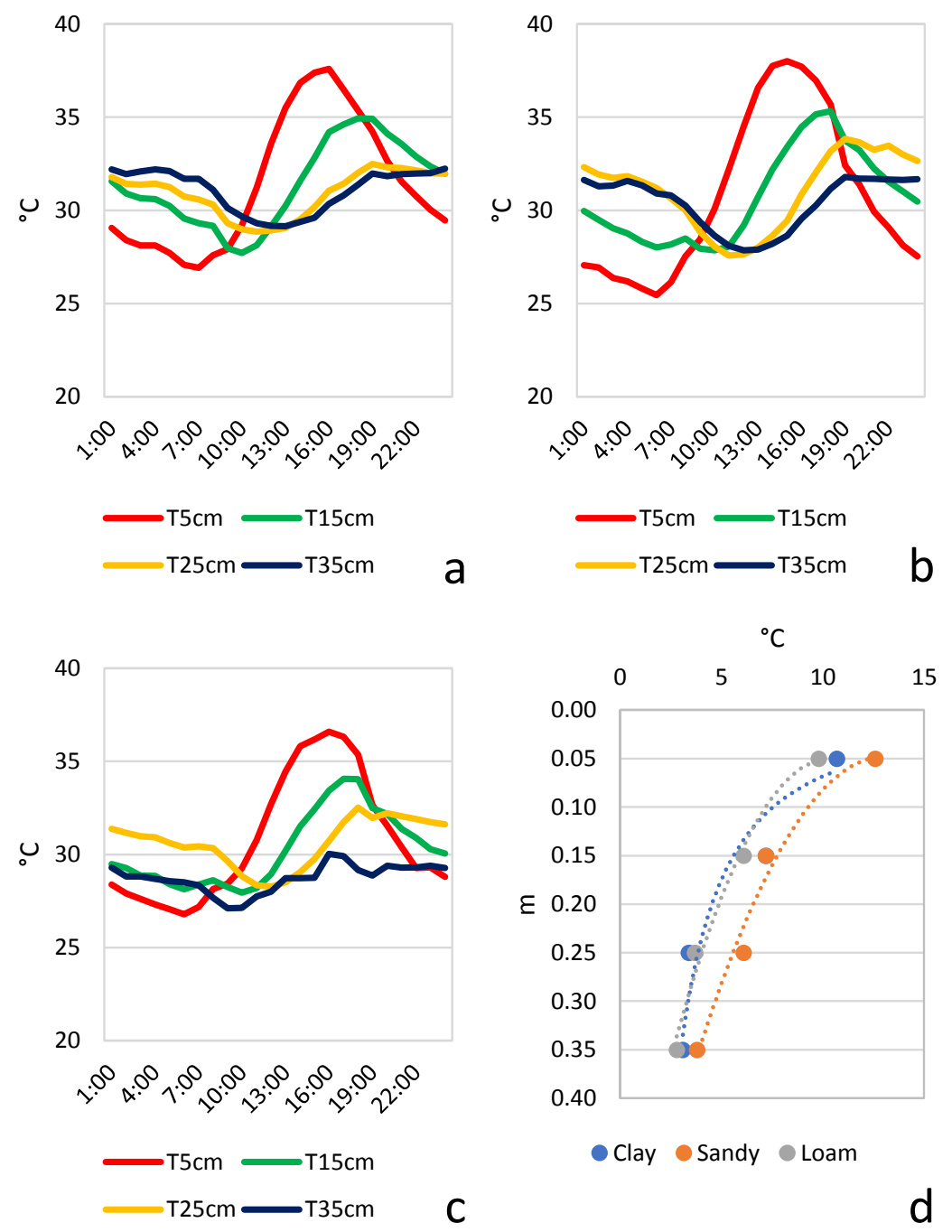

Figure 6. Mean hourly soil temperature patterns throughout the day for three different soils: loam (a), sand (b), and sandy clay loam (c). Thermal amplitude pattern for the same soils (d)

\subsection{Correlation Analyses}

Autocorrelation plots of the average hourly data show the temperature pattern throughout the day. Air and soil temperature are firmly autocorrelated; all the plots (Figure 7) show high autocorrelation at lag one (a little less than 1) that gradually declines until lag three. It continues decreasing rapidly until lags eight through ten, depending on the depth and soil type. After lag six, the correlation becomes negative, and it gradually stops decreasing between lags eleven and twelve. There are three exceptions to this pattern: the deepest layer $\left(\mathrm{T}_{35 \mathrm{~cm}}\right)$ of sand soil and the third $\left(\mathrm{T}_{25 \mathrm{~cm}}\right)$ and deepest $\left(\mathrm{T}_{35 \mathrm{~cm}}\right)$ layers of the sandy clay loam soil. At those depths and soils, the pattern has slight changes: in the sand $\left(T_{35 \mathrm{~cm}}\right)$ and sandy clay loam $\left(\mathrm{T}_{25 \mathrm{~cm}}\right)$ soils, the correlation decreases until lag eight. In the sandy clay loam $\left(\mathrm{T}_{35 \mathrm{~cm}}\right)$ soil, the correlation rapidly decreases from lag one to lag eight (Figure 7). 


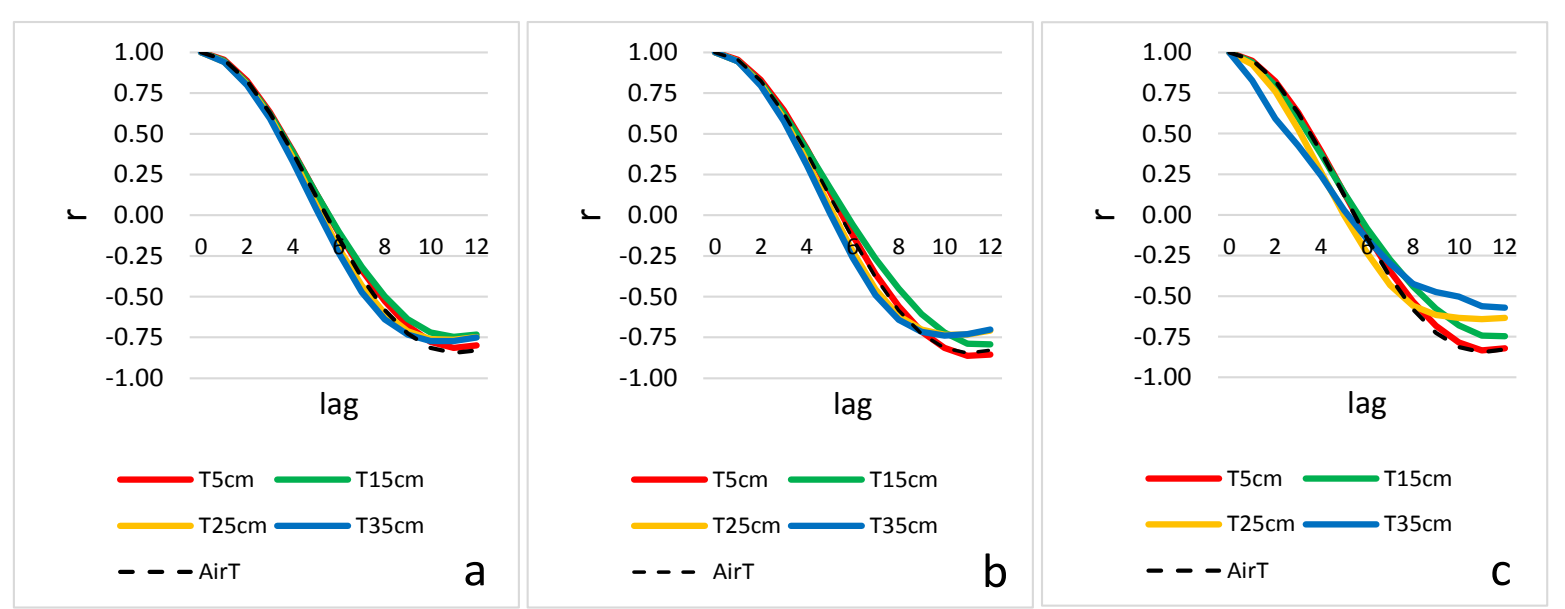

Figure 7. Autocorrelation plots for five variables analyzed, including air temperature, for each soil type: loam (a), sand (b), and sandy clay loam (c)

Cross-correlation plots confirm a relationship between the temperature of each soil layer and the temperature of the layers in contact with it. However, the lag at which the highest correlation coefficient appears is different for the layers and soils. There is a high relation between air temperature and the first soil layer $\left(\mathrm{T}_{5 \mathrm{~cm}}\right)$. Air temperature changes lead to immediate changes in topsoil layer temperatures (Table 2), which is especially evident in the sandy soil. The first layer's temperature changes lead to changes in the second layer after three hours. Variations in the second soil layer $\left(\mathrm{T}_{15 \mathrm{~cm}}\right)$ affect the third layer $\left(\mathrm{T}_{25 \mathrm{~cm}}\right)$ three hours after the change in the second one. However, there is a slight difference in the pattern for the loamy soil (Table 2). The highest correlation between the third $\left(\mathrm{T}_{25 \mathrm{~cm}}\right)$ and the fourth $\left(\mathrm{T}_{35 \mathrm{~cm}}\right)$ layer of soil appears with no or one hour of lag. For the sandy clay loam soil, that correlation is weak with no lag, while, for the other soils, fluctuations in temperature in the third layer cause fluctuation in the fourth layer after two hours (lag 2). Parameters for the linear equations of the highest correlations between layers appear in Table 3.

\section{Discussion}

\subsection{Soil Temperature as an Air Temperature Function}

In equatorial regions such as the Cauca River Valley, day length and daily values of solar radiation and air temperature have no substantial variation throughout the year (Figures 1 and 2). Under these conditions, hourly variations of weather elements are higher than those of daily mean climate values (Figure 2).

As a response to the conditions described, hourly mean soil temperature values of the top layers $\left(\mathrm{T}_{5 \mathrm{~cm}}\right.$ and $\left.\mathrm{T}_{15 \mathrm{~cm}}\right)$ also show higher variability than do daily mean soil temperature values. Therefore, in contrast to what occurs in bare soils of mid and high latitude regions (e.g., Oliveira et al., 2001; Awe et al., 2015; Staniec \& Nowak, 2016), in bare soils of equatorial regions, the pattern of temperature at a given depth does not vary throughout the year. Contrary to Staniec and Nowak's (2016) findings, we do not expect that subsurface soil layers reach higher temperatures than the top layer does, as can occur between late fall and early spring in other latitudes.

Considering that solar radiation is the primary input for increasing the soil temperature, there is no substantial temporal variation of this element in the Cauca River Valley. Furthermore, considering the energy balance, in bare soils of the equatorial regions, temporal changes of net radiation over the same type of soil are only related to soil chroma changes associated with humidity fluctuations, which cause a variation in albedo values (Post et al., 2000).

The reported higher values of thermal conductivity and thermal diffusivity of sandy soils (Moene \& van Dam, 2014; Campbell \& Norman, 1998) determined the higher thermal amplitude of this soil in the profile (Figures 5 and 6). The coefficient correlation values between air temperature and $\mathrm{T}_{5 \mathrm{~cm}}$ (Table 2) are higher for sand soils, which has been reported with a higher thermal conductivity than loamy soils by several authors (Moene \& van Dam, 2014; Campbell \& Norman, 1998). Meanwhile, the slope and intercept values reported in Table 3 may explain the differences in the rate at which temperature changes with depth, similar to the concept of diffusivity, and the maximum temperature reached by a layer when the precedent layer gets frozen, similar to the concept of heat storage capacity. 
From this standpoint, taking into account that the soil temperature patterns do not exhibit significant changes during the sowing season, the use of empirical expressions can be considered as an efficient tool for obtaining soil temperature data based on air temperature. For example, models based on dynamic regression, linear transfer functions, and intervention analysis should be an alternative (Plasmans, 2006) for obtaining expressions that relate air and soil temperature at different depths.

\subsection{Management Insights}

In general, in this short experiment, we found that the average daily temperature along the first $0.4 \mathrm{~m}$ of soil varies between $29^{\circ} \mathrm{C}$ (deepest layers) and $32{ }^{\circ} \mathrm{C}$ (upper layer). Therefore, the average daily temperature of the soil is 5 to $7^{\circ} \mathrm{C}$ higher than the average air temperature. Therefore, assuming that sugar cane varieties planted in the region are similar to those reported by James (2004), soil temperature for root growth is sub-optimum. In this sense, we could think that the new management scenario would represent adverse conditions for buds during the transitional period between dry and rainy seasons (Figure 6). That is because, according to Marín (2008), bud germination's ideal temperature is between $32{ }^{\circ} \mathrm{C}$ and $38^{\circ} \mathrm{C}$. In this case, to put cane stalks buried under a soil layer of $0.05 \mathrm{~m}$ would guarantee better conditions for buds than under any other depth. It should be the reason why, in the Cauca River Valley, for sowing, cane stalks are buried that deep (Viveros \& Calderón, 1995). Under the new proposed management scenario, the three analyzed soils only reach the optimum temperature in the first layer $\left(\mathrm{T}_{5 \mathrm{~cm}}\right)$ during the day (Figure 4$)$. Despite the probability of getting to the optimum temperature at night in the deepest layers, burying stalks at greater depth would mean a challenge for leaves to reach the surface. In the first layer $\left(\mathrm{T}_{5 \mathrm{~cm}}\right)$, the highest probability of having more hours per day with temperatures higher than $32{ }^{\circ} \mathrm{C}$ is in loam rather than in sand and sandy clay loam soils.

Nevertheless, the higher probability of having temperatures greater than $38^{\circ} \mathrm{C}$ was in the sand soil (Appendix C). Interestingly, under the assumption that Marin's (2008) germination optimum temperature values adequately account for the Colombian sugarcane varieties response to soil temperature, would not be affected if growers use the recommendation by Viveros and Calderon (1995). However, based on a review, Whiteman (1963) concluded there are marked varietal differences in the response of bud germination to soil temperature. Analyzing the optimum value for bud sprout, suggested by this author $\left(30^{\circ} \mathrm{C}\right)$, the most convenient site for germination and subsequent shoot growth of sugarcane cuttings is at $0.15 \mathrm{~m}$ depth in three analyzed soils (Figure 6). On the other hand, considering Onwuka and Brown's (2018) report, under the new management scenario, the three Cauca River Valley's representative soils would have the optimum temperature for microorganism's development in the first $0.4 \mathrm{~m}$ of depth. However, in this profile, there are no ideal conditions for the development of macroorganisms.

Table 2. Correlation coefficients for the cross correlograms. Shaded values indicate p-value $>0.05$

\begin{tabular}{|c|c|c|c|c|c|c|c|c|c|c|c|c|c|c|}
\hline & & \multicolumn{13}{|c|}{ Air Temperature (AT) } \\
\hline & & Lag 0 & Lag1 & Lag 2 & Lag 3 & Lag 4 & Lag 5 & Lag 6 & Lag 7 & Lag 8 & Lag 9 & Lag 10 & Lag 11 & Lag 12 \\
\hline \multirow{4}{*}{$\mathrm{T}_{5 \mathrm{~cm}}$} & Loam & 0.80 & 0.84 & 0.80 & 0.73 & 0.54 & 0.35 & 0.15 & -0.05 & -0.22 & -0.42 & -0.48 & -0.57 & -0.62 \\
\hline & Sand & 0.84 & 0.82 & 0.73 & 0.61 & 0.38 & 0.17 & -0.05 & -0.25 & -0.41 & -0.58 & -0.59 & -0.65 & -0.65 \\
\hline & SCL & 0.82 & 0.84 & 0.78 & 0.69 & 0.49 & 0.29 & 0.08 & -0.13 & -0.30 & -0.49 & -0.53 & -0.62 & -0.64 \\
\hline & & \multicolumn{13}{|c|}{$\mathrm{T}_{5 \mathrm{~cm}}$} \\
\hline \multirow{4}{*}{$\mathrm{T}_{15 \mathrm{~cm}}$} & Loam & 0.45 & 0.66 & 0.79 & 0.88 & 0.84 & 0.77 & 0.64 & 0.49 & 0.33 & 0.11 & -0.02 & -0.22 & -0.39 \\
\hline & Sand & 0.56 & 0.72 & 0.82 & 0.88 & 0.81 & 0.72 & 0.57 & 0.40 & 0.22 & -0.01 & -0.14 & -0.35 & -0.50 \\
\hline & SCL & 0.66 & 0.78 & 0.82 & 0.83 & 0.71 & 0.58 & 0.42 & 0.24 & 0.08 & -0.14 & -0.24 & -0.42 & -0.54 \\
\hline & & \multicolumn{13}{|c|}{$\mathrm{T}_{15 \mathrm{~cm}}$} \\
\hline \multirow{4}{*}{$\mathrm{T}_{25 \mathrm{~cm}}$} & Loam & 0.60 & 0.74 & 0.80 & 0.83 & 0.73 & 0.62 & 0.47 & 0.30 & 0.13 & -0.08 & -0.15 & -0.28 & -0.40 \\
\hline & Sand & 0.29 & 0.52 & 0.68 & 0.80 & 0.80 & 0.78 & 0.71 & 0.60 & 0.47 & 0.28 & 0.19 & 0.01 & -0.17 \\
\hline & SCL & 0.35 & 0.56 & 0.68 & 0.78 & 0.75 & 0.70 & 0.62 & 0.53 & 0.42 & 0.25 & 0.17 & -0.01 & -0.17 \\
\hline & & \multicolumn{13}{|c|}{$\mathrm{T}_{25 \mathrm{~cm}}$} \\
\hline \multirow{3}{*}{$\mathrm{T}_{35 \mathrm{~cm}}$} & Loam & 0.73 & 0.80 & 0.79 & 0.75 & 0.59 & 0.42 & 0.22 & 0.02 & -0.15 & -0.32 & -0.34 & -0.42 & -0.48 \\
\hline & Sand & 0.79 & 0.83 & 0.77 & 0.68 & 0.48 & 0.28 & 0.07 & -0.13 & -0.28 & -0.42 & -0.40 & -0.44 & -0.48 \\
\hline & SCL & 0.53 & 0.29 & 0.08 & -0.05 & -0.21 & -0.30 & -0.36 & -0.40 & -0.41 & -0.46 & -0.42 & -0.43 & -0.38 \\
\hline
\end{tabular}


Table 3. Linear regression coefficients $(y=m x+b)$ for the higher correlations detected in the cross correlogram

\begin{tabular}{|c|c|c|c|}
\hline Soil type & Slope $(m)$ & $X$ & Intercept $(b)$ \\
\hline \multirow{4}{*}{ Loam } & 1.153 & $\mathrm{AT}_{\mathrm{t}-1}$ & 3.307 \\
\hline & 0.617 & $\mathrm{~T} 5 \mathrm{~cm}_{\mathrm{t}-3}$ & 12.002 \\
\hline & 0.504 & $\mathrm{~T} 15 \mathrm{~cm}_{\mathrm{t}-3}$ & 15.040 \\
\hline & 0.892 & $\mathrm{~T} 25 \mathrm{~cm}_{\mathrm{t}-1}$ & 3.503 \\
\hline \multirow{4}{*}{ Sand } & 1.402 & $\mathrm{AT}_{\mathrm{t} 0}$ & 3.385 \\
\hline & 0.551 & $\mathrm{~T} 5 \mathrm{~cm}_{\mathrm{t}-3}$ & 13.774 \\
\hline & 0.742 & $\mathrm{~T} 15 \mathrm{~cm}_{\mathrm{t}-4}$ & 8.220 \\
\hline & 0.680 & $\mathrm{~T} 25 \mathrm{~cm}_{\mathrm{t}-1}$ & 9.245 \\
\hline \multirow{4}{*}{ SCL } & 1.077 & $\mathrm{AT}_{\mathrm{t}-1}$ & 4.550 \\
\hline & 0.572 & $\mathrm{~T} 5 \mathrm{~cm}_{\mathrm{t}-2}$ & 12.665 \\
\hline & 0.571 & $\mathrm{~T} 15 \mathrm{~cm}_{\mathrm{t}-3}$ & 13.316 \\
\hline & 0.402 & $\mathrm{~T} 25 \mathrm{~cm}_{\mathrm{t} 0}$ & 16.420 \\
\hline
\end{tabular}

These results are a primary source of information for crop breeders and agronomists. Crop breeders can use the results by considering soil temperature in the future selection of varieties and selecting varieties for the new soil temperature scenario. Agronomists can use this information to design crop management that reduces the effect of changing soil temperature, associated with bare soils during the first sugarcane growing stages. Crop management would focus on using different planting depths for planting canes and using practices for maintaining optimal temperatures for root water and nutrient uptake in ratooning.

\section{Conclusion}

Little attention has been paid to the effect of soil temperature as a sugarcane and soil-biota stressor. Research has concentrated on knowing the effect of soil humidity on sugarcane growth and development. Air temperature, a variable measured and characterized along the Cauca River Valley could be used as a predictor in models to obtain soil temperature. In this short paper, we found that soil temperature values obtained in a new planting and ratooning scenario could affect the time with optimum conditions for bud burst and root growth, and therefore, new management should consider the use of different planting depths, according to soil types. It is essential to highlight that soil temperature data is scarce in Colombia, and despite this short step for knowing that variable, a limitation for this type of study in equatorial regions is the lack of information for making comparisons.

\section{References}

Asocaña. (2020). Aspectos generales del sector agroindustrial de la caña 2018-2019. Informe Anual (p. 95). Asociación de Cultivadores de Caña de Azúcar de Colombia (Asocaña). Retrieved from https://www.asocana.org/documentos/2352019-D0CA1EED-00FF00,000A000,878787,C3C3C3,0F0F0F,B4 B4B4,FF00FF,2D2D2D,A3C4B5.pdf

Awe, G., Reichert, J., \& Wendroth, O. (2015). Temporal variability and covariance structures of soil temperature in a sugarcane field under different management practices in southern Brazil. Soil and Tillage Research, 150, 93-106. https://doi.org/10.1016/j.still.2015.01.013

Bragagnolo, N., \& Mielniczuk, J. (1990). Cobertura do solo por palha de trigo e seu relacionamento com a temperatura e umidade do solo. Revista Brasileira de Ciência do Solo, 14(3), 369-373.

Campbell, G., \& Norman, J. (1998). An introduction to environmental biophysics (2nd ed., p. 286). Springer. https://doi.org/10.1007/978-1-4612-1626-1

Davin, E. L., Seneviratne, S. I., Ciais, P., Olioso, A., \& Wang, T. (2014). Preferential cooling of hot extremes from cropland albedo management. Proceedings of the National Academy of Sciences, 111(27), 9757-9761. https://doi.org/10.1073/pnas.1317323111

Derrick, T. R., \& Thomas, J. M. (2004). Time series analysis: The cross-correlation function. In N. Stergiou (Ed.), Innovative Analyses of Human Movement (pp. 189-205). Champaign, IL: Human Kinetics. Retrieved from https://lib.dr.iastate.edu/cgi/viewcontent.cgi?article=1045\&context=kin_pubs

Hunsigi, G. (1993) Soil and Climatic Requirements. Production of Sugarcane. Advanced Series in Agricultural Sciences (Vol. 21). Springer, Berlin, Heidelberg. https://doi.org/10.1007/978-3-642-78133-9 
James, G. (2004). Introduction to Sugarcane. In G. James (Eds.), Sugarcane (pp. 1-19). Oxford: Wiley-Blackwell. https://doi.org/10.1002/9780470995358

Moene, A., \& van Dam, J. (2014). Transport in the atmosphere-vegetation-soil continuum (p. 436). Cambridge University Press, UK. https://doi.org/10.1017/CBO9781139043137

Oliveira, J., Timm, L., Tominaga, T., Cassaro, F., Reichardt, K., Bacchi, O., \& Câmara, G. (2001). Soil temperature in a sugar-cane crop as a function of the management system. Plant and Soil, 230, 61-66. https://doi.org/10.1023/A:1004820119399

Onwuka, B., \& Brown, M. (2018). Effects of Soil Temperature on Some Soil Properties and Plant Growth. Adv Plants Agric Res, 8(1), 34-37. https://doi.org/10.15406/apar.2018.08.00288

Peña, A., Chaves, B., Salazar, M., Keller, M., \& Hoogenboom, G. (2019). Radius of influence of air temperature from automated weather stations installed in complex terrain. Theoretical and Applied Climatology, 137(3-4), 1957-1973. https://doi.org/10.1007/s00704-018-2717-9

Peña, A., Chica, H., \& Mendoza, C. (2020). El clima de la región productora de caña de azúcar en el Valle del río Cauca. In F. Garces, et al. (Eds.), La caña de azúcar en el valle del río Cauca. Cenicaña.

Plasmans, J. (2006). Modern Linear and Nonlinear Econometrics (p. 381). Springer-Verlag New York Inc.

Post, D., Fimbres, A., Matthias, A., Sano, E., Accioly, L., Batchily, A., \& Ferreira, L. (2000). Predicting Soil Albedo from Soil Color and Spectral Reflectance Data. Soil Science Society of America Journal, 64(3), 1027-1034. https://doi.org/10.2136/sssaj2000.6431027x

Santos, F., Queiroz, J., Colodette, J., Fernandes, S., Guimaraes, V., \& Rezende, S. (2012). Potencial da palha de cana-de-açúcar para produção de etanol. Quim. Nova, 35(5), 1004-1010. https://doi.org/10.1590/S0100-404 22012000500025

Staniec, M., \& Nowak, H. (2016). The application of energy balance at the bare soil surface to predict annual soil temperature distribution. Energy and Buildings, 127, 56-65. https://doi.org/10.1016/j.enbuild.2016. 05.047

Tenelli, S., de Oliveira Bordonal, R., Barbosa, L. C., \& Carvalho, J. L. N. (2019). Can reduced tillage sustain sugarcane yield and soil carbon if straw is removed? BioEnergy Research, 12(4), 764-777. https://doi.org/10.1007/s12155-019-09996-3

Tumuluru, J. S., Tabil, L. G., Song, Y., Iroba, K. L., \& Meda, V. (2014). Impact of process conditions on the density and durability of wheat, oat, canola, and barley straw briquettes. BioEnergy Research, 8(1), 388-401. https://doi.org/10.1007/s12155-014-9527-4

Valverdi, N. A., Cheng, L., \& Kalcsits, L. (2019). Apple Scion and Rootstock Contribute to Nutrient Uptake and Partitioning under Different Belowground Environments. Agronomy, 9(8), 415. https://doi.org/10.3390/ agronomy 9080415

Viveros, C., \& Calderón, H. (1995). Siembra. CENICAÑA (pp. 131-139). El cultivo de la caña de azúcar en la zona azucarera de Colombia, Cali, CENICAÑA.

White, R. (2015). Understanding vineyard soils (2nd ed., p. 280). Oxford University Press, New York.

Whiteman, P., Bull, T., \& Glasziou, K. (1963). The physiology of sugarcane; VI: Effects of temperature, light, and water on set germination and early growth (Saccharum spp.). Australian J. Biological Science, 16(2), 416-428. https://doi.org/10.1071/BI9630416 


\section{Appendix A}

Location of the Cauca river valley (dark gray line) and Cenicaña (white circle)
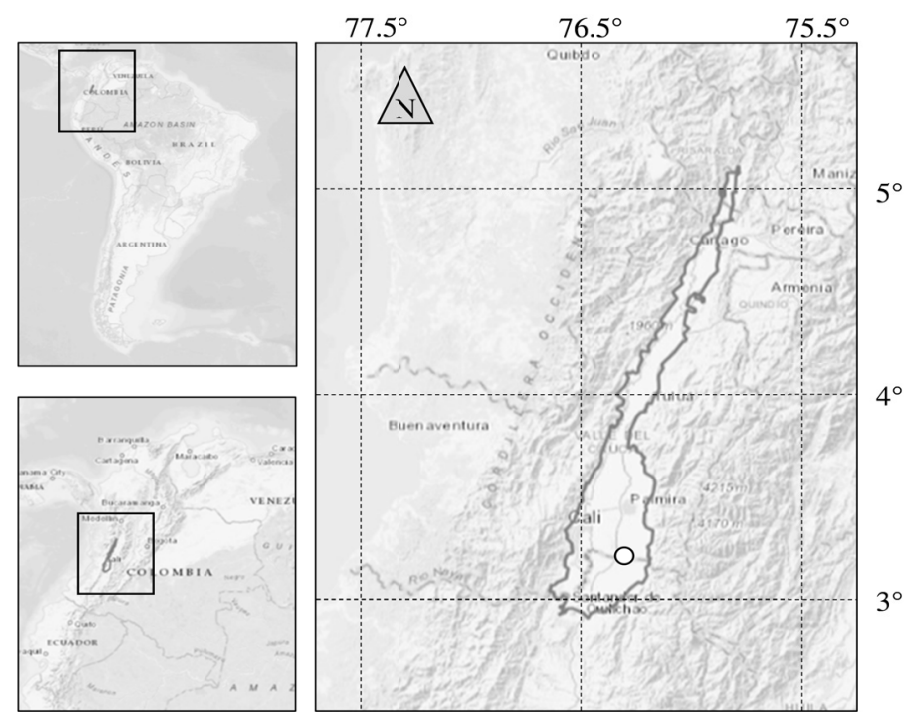

\section{Appendix B}

Hourly data collected by dataloggers, between 02-28 and 04-21, for three soil types at four different depths: $0.05 \mathrm{~m}(\mathrm{a}), 0.15 \mathrm{~m}(\mathrm{~b}), 0.25 \mathrm{~m}(\mathrm{c})$, and $0.35 \mathrm{~m}(\mathrm{~d})$. SCL is sandy clay loam

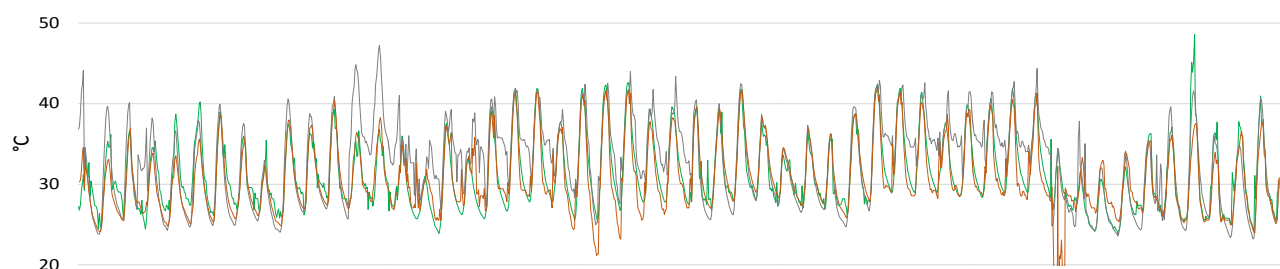

20

50

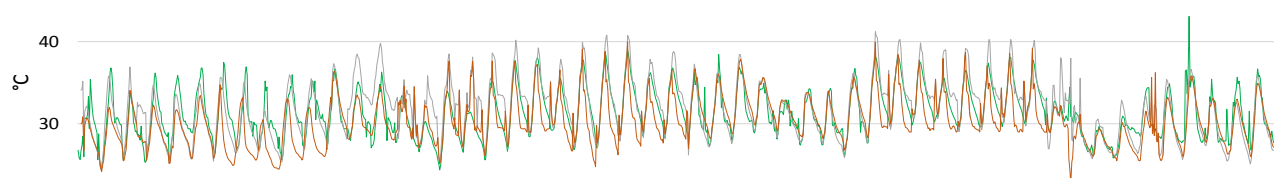

20

50

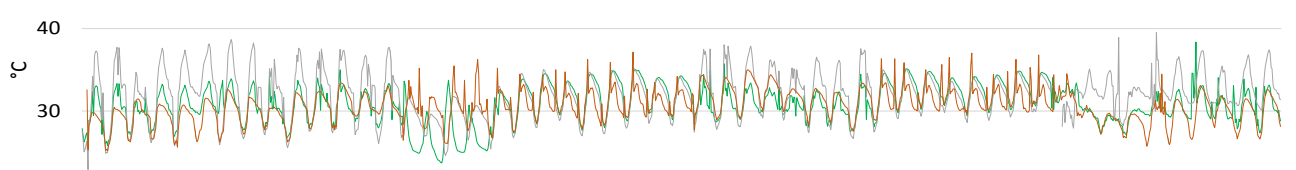

20

50

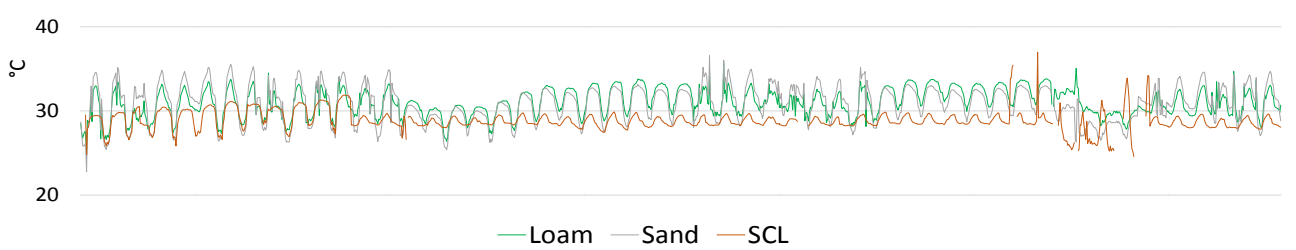

(d) 


\section{Appendix C}
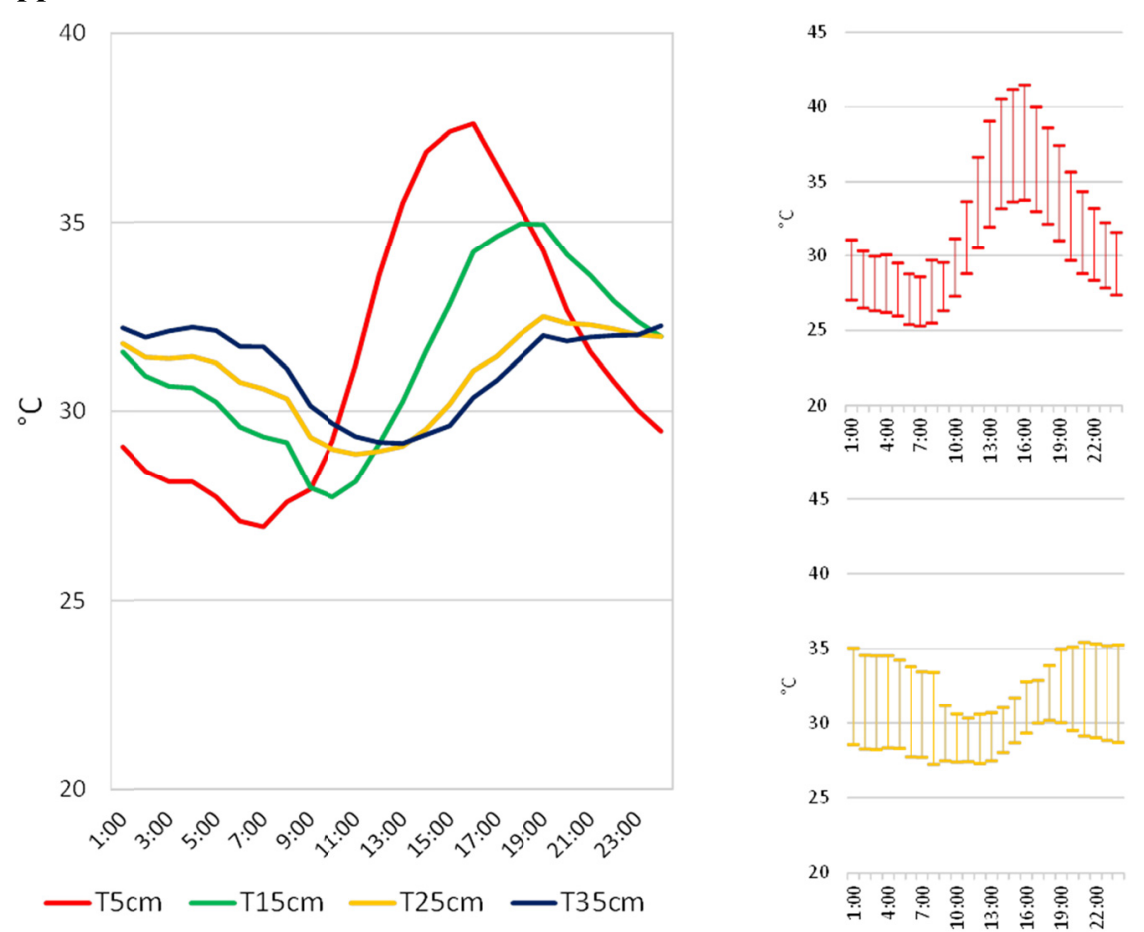

45
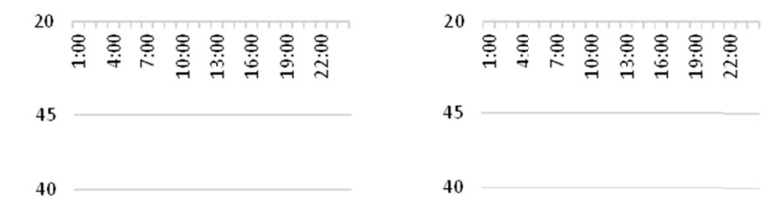

45
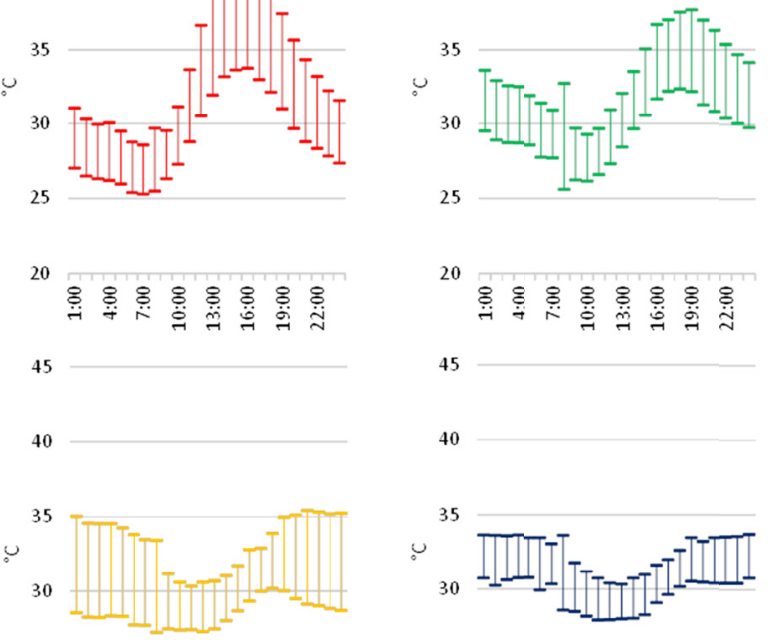

40

25

${ }^{20}$ 各

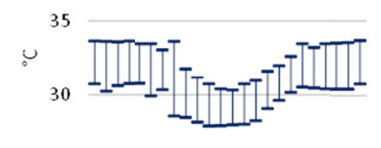

25

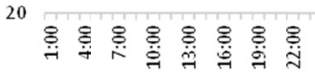

Appendix C1. Mean and standard deviation of hourly soil temperature data for the loam soil
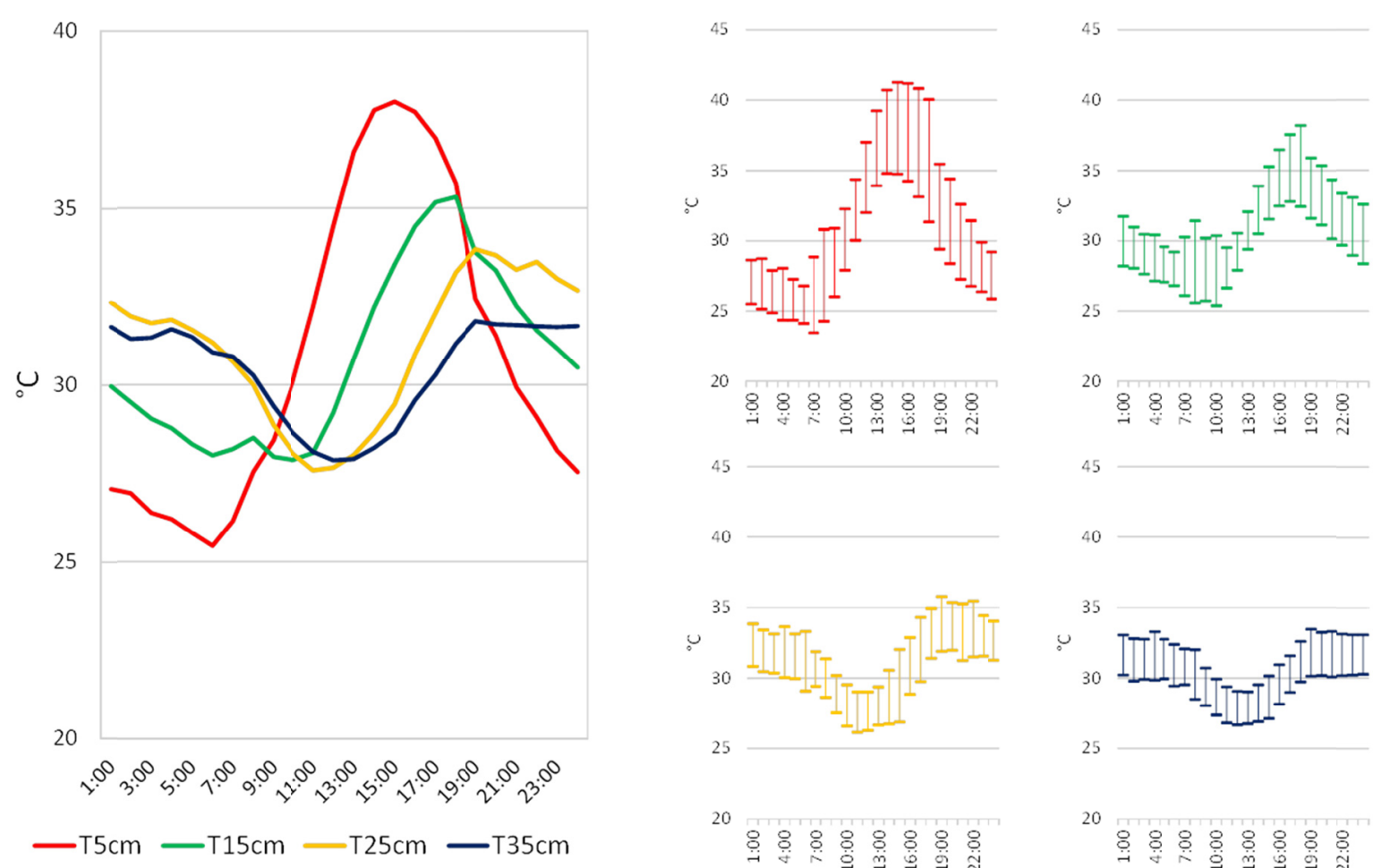

25

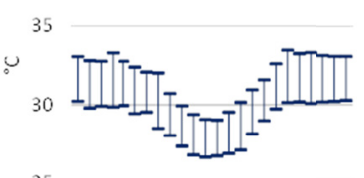

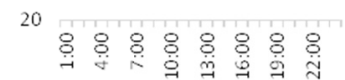

25

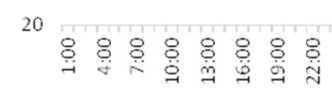

Appendix C2. Mean and standard deviation of hourly soil temperature data for the sand soil 

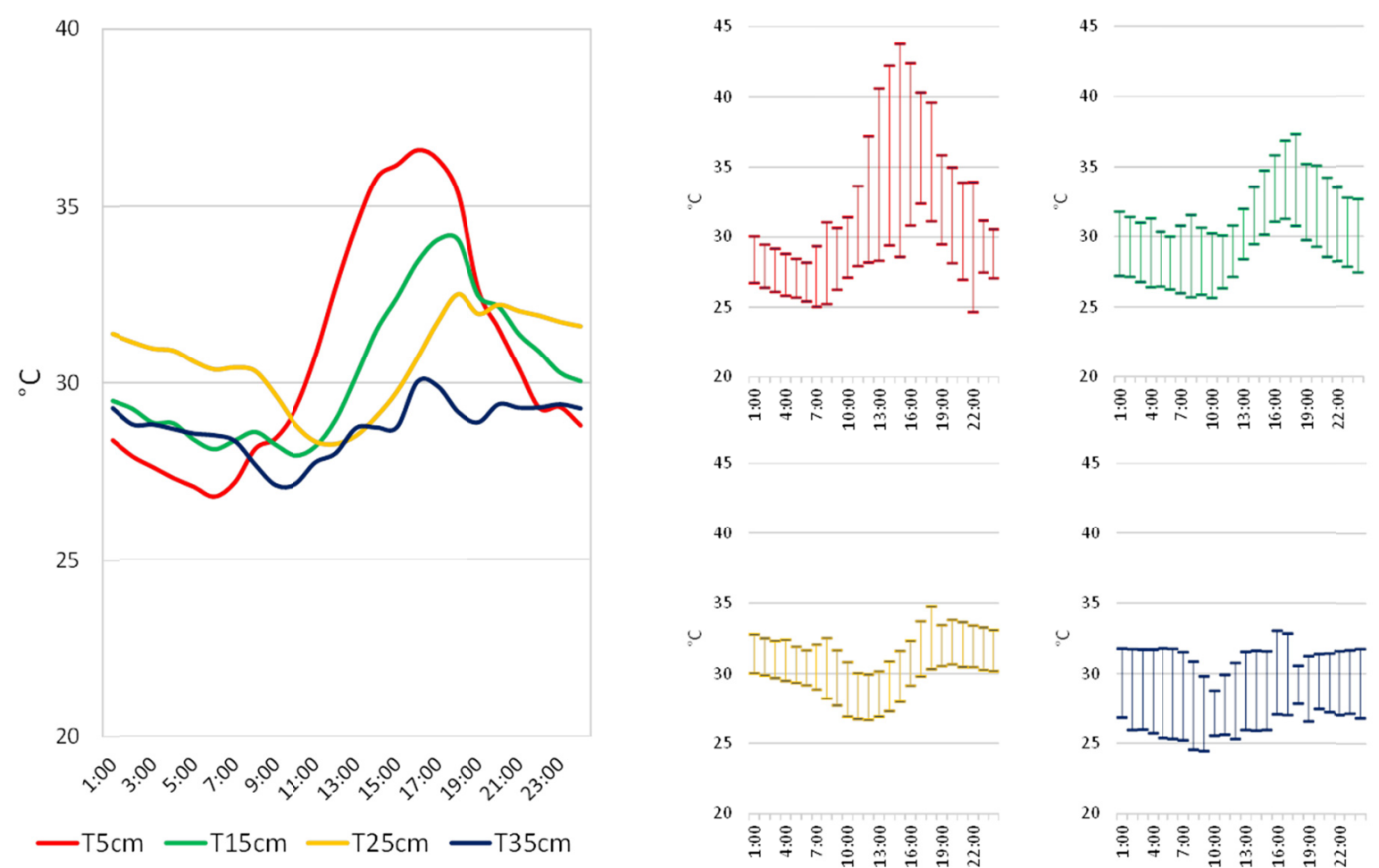

45

45
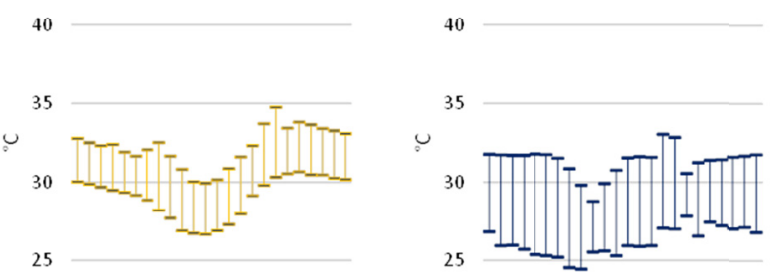

20

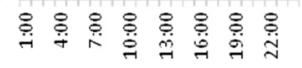

20

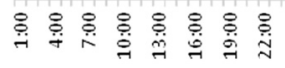

Appendix C3. Mean and standard deviation of hourly soil temperature data for the sandy clay loam soil

\section{Copyrights}

Copyright for this article is retained by the author(s), with first publication rights granted to the journal.

This is an open-access article distributed under the terms and conditions of the Creative Commons Attribution license (http://creativecommons.org/licenses/by/4.0/). 